\title{
Viability of Pineapple Leaves as an Alternative Natural Fiber Geotextile
}

\author{
Oliver C. Celis ${ }^{1, *}$ \\ ${ }^{I}$ College of Civil Engineering, Our Lady of Fatima University - Philippines, 2000 \\ *Corresponding author: oliver.celis@upd.edu.ph
}

\begin{abstract}
The study focuses on the utilization of pineapple leaves fiber as a raw material for the production of geotextiles. The fiber yarns were weaved based on required size of sample issued by the Philippines Textile Research Institute (PTRI) of the Department of Science and Technology (DOST). The Zwick/Roell Tensile Strength Tester Z050 (CRE) with 50 KN full scale load was used with the Wide-Width Strip Method in order to get the average tensile strength of the specimens each for both pineapple and abaca geotextile samples. The resulting average tensile strength and average nominal thickness for pineapple leaves geo-textile, when compared to abaca geo-textile has higher tensile force for a thinner sample of pineapple leaf geo-textile.
\end{abstract}

Keywords- natural fiber, pineapple leaves, geo-textile, abaca.

\section{INTRODUCTION}

G eotextiles have been used for thousands of years.

Geotextiles were used in roadway construction in the days of the pharaohs to stabilize roadways and their edges. These early geotextiles were made of natural fibers, fabrics or vegetation mixed with soil to improve road quality, particularly when roads were made on unstable soil. Only recently have geotextiles been used and evaluated for modern road construction.

Natural fiber geotextiles degrade to form organic mulch and help in quick establishment of vegetation. Natural fibers, like jute, coir, sisal, etc. have quite a few inherent properties suited to meet the requirements of different types of geotextiles. Shorter durability of natural geotextiles is a matter of apparent concern of end-users in general, though their ecocompatibility gives them an edge over man-made geotextiles.

Today, the idea of using agricultural waste as a renewable resource became a positive option. Greater supplies of natural geotextile materials are required than at any previous time in man's history. Attention must be given in finding technology to come up with substitute materials without additional unnecessary impacts to nature. Thus, the increasing demand for natural resources is one of the great challenges to man.

In developing countries, there is a different approach to deal with organic waste. In fact, the word 'waste' is often an inappropriate term for organic matter, which is often put to good use. The economies of most developing countries dictate that materials and resources must be used to their full potential, and this has propagated a culture of reuse, repair and recycling. In many developing countries, there exists a whole sector of recyclers, scavengers and collectors, whose business is to salvage ' waste' material and reclaim it for further use.

Pineapple is the second harvest of importance after bananas, contributing to over $20 \%$ of the world production of tropical fruits (Coveca, 2002). Nearly $70 \%$ of the pineapple is consumed as fresh fruit in producing countries. Its origin has been traced to Brazil and Paraguay in the Amazonic basin where the fruit was domesticated. Thailand, Philippines, Brazil and China are the main pineapple producers in the world supplying nearly $50 \%$ of the total output (FAO, 2004).

In 2011, Philippines have an existing production area of 58,457 hectares that has produced a volume of $2,246,806$ MT. Pineapple production went up by $3.58 \%$ in 2011. There were continuous increases in areas harvesting of pineapple from Del Monte, Lapanday, Asian Hybrid, Mt. Kitanglad Agricultural Development Corporation, Davao Ventures Corporation and DOLE in Bukdinon in the 2nd half of 2011. Higher yield of pineapple farms were cited in SOCCSKSRAGEN and this was attributed to sufficient rainfall during the last quarter of the year. Northern Mindanao attained the highest production followed by SOCCSKSARGEN and Bicol Region. On the other hand, SOCCSKSARGEN has the highest existing area of 22,850 hectares, followed by Northern Mindanao with 21,979 hectares and CALABARZON with 3,869 hectares. (Department of Agriculture. (2013). PRODUCTION (Bureau of Agricultural Statistics), from http://hvcdp.da.gov.ph/pineapple.htm).

Pineapple, aside from fruits as its main product, has different plant parts that can be good sources of various industrial products. Pineapple leaves are waxy, strap-shaped leaves 2 to 6 feet in length. They usually have a sharp point on the tip of the leaf and spines along the margins of the leaves. Processing of 


\section{The Third International Conference on Civil Engineering Research (ICCER) August $1^{\text {st }}-2^{\text {nd }}$ 2017, Surabaya-Indonesia}

pineapple leaf to provide value-added products is a better approach to reduce the waste for a sustainable agriculture industry. The fiber can be used to produce a wide range of products for diverse applications.

One of the reasons why the pineapple leaves should be considered for use is because of its numerous benefits and uses. Commercially, pineapple fruits are very important and leaves are considered as waste materials of fruit, which is being used for producing natural fibers. Pineapple (PALF) has tremendous mechanical properties and can be applied in making reinforced polymer composites. With this, the idea of pineapple leaves as an alternative material in the development and innovation of geotextile has been used in the study.

At present, geotextile-related materials such as fabrics formed into mats, webs, nets, grids, or formed plastic sheets are not the same as geotextiles. Although geotextiles have historically been made of natural plant, modern geotextiles are usually made from a synthetic polymer (such as polypropylene, polyester, polyethylenes and polyamides) or a composite of natural and synthetic material. Plant fiber-based erosion control geotextiles are subject to decomposition and have a limited shelf life before their inherent durability suffers. The synthetic polymers have the advantage of not decaying under biological and chemical processes, but being a petrochemical-based product they use non-renewable resources in their construction, and cause environmental pollution in their manufacture and use, and have associated health risks. Geotextiles are usually used in different applications such as slope protection and stabilization, filtration, separation, promoting vegetation, and in many geotechnical engineering applications. These are also used for sand dune armoring to protect upland coastal property from storm surge, wave action and flooding.

Geotextiles and related products have many applications and currently support many civil engineering applications. Researchers are needed to innovate new ideas and explore the potential of geotextile in this field of engineering.

The intent of this study is to determine the viability of pineapple leaves as an alternative raw material in the production of natural fiber geotextile.

\section{METHODS AND MATERIALS}

\section{A. Preparation of Sample}

Discarded pineapple leaves were collected from a pineapple plantation in Banaba, Batangas City. Leaf margins were peeled off from the blade. The pineapple leaves were then thoroughly water-washed to remove impurities.

The water content was then removed from the Pineapple leaves by means of manual extraction. The process of extraction required certain care to avoid the damage. Impurities in the rolled fibers such as pigments, broken fibers, and coating of cellulose were removed manually, and then fibers were cleaned and dried. The pineapple fibers were sundried to remove excess moisture from the materials in order to attain the target condition of the extracted fiber.

After the fiber is produced, the next process is the spinning of extracted yarns. This can be done by wheel spinning, by mechanical spinning or by hand spinning. Wheel spin yarns are of uniform good quality.

The quality of yarn is evaluated based on its thickness, color, appearance, uniformity in twist, strength, fineness, texture, etc. In the study, the researchers prepared to use the hand spinning method of producing yarn.

\section{Process}

\section{Collection of Pineapple Leaves}

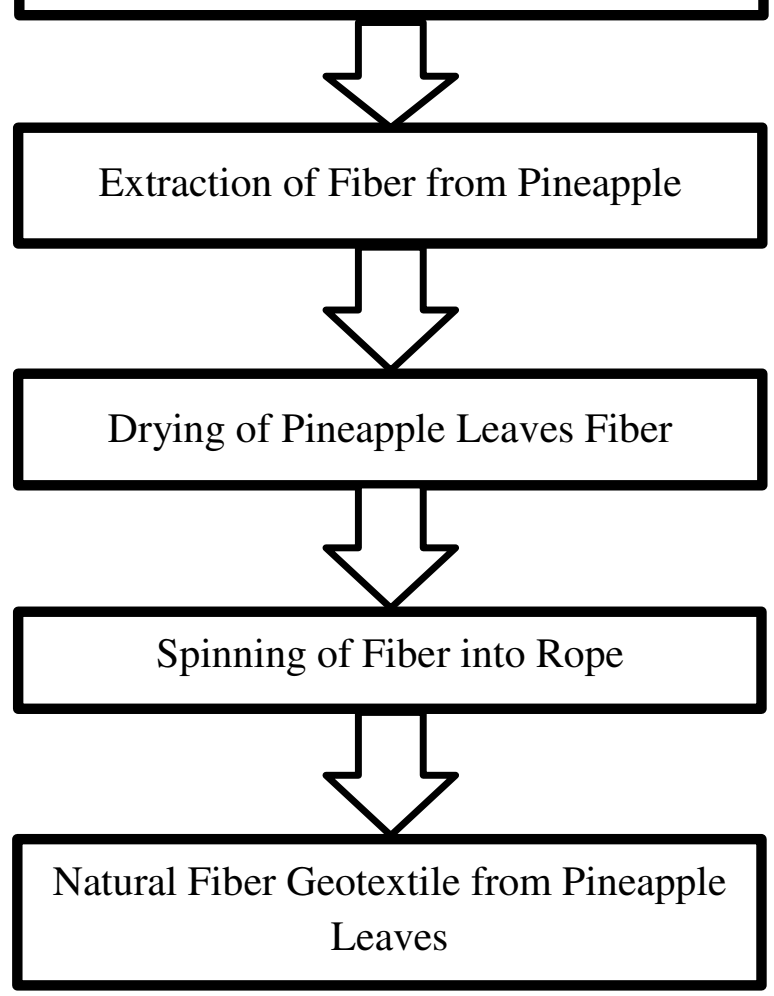

Figure 1. Process Flow of Pineapple Leaves Geotextile Production

The Pineapple leaves fiber was tied into a wood and then manually spanned by hand to produce the estimated 180 meters of rope that is needed to make six pineapple geotextile samples.

This is a method of textile production in which two distinct sets of yarns or threads are interlaced at right angles to form a fabric and textile. The other methods are knitting, lace making, felting, and braiding or plaiting. The longitudinal threads are called the warp and the lateral threads are the weft or filling. The 


\section{The Third International Conference on Civil Engineering Research (ICCER) August $1^{\text {st }}-2^{\text {nd }}$ 2017, Surabaya-Indonesia}

method in which these threads are woven affects the characteristics of the textile.

The geotextile formed has dimensions of $300 \mathrm{~mm} x$ $200 \mathrm{~mm}$. This was the sample tested for physical and mechanical test.

Several steps were done in the manufacturing process of Pineapple Fiber Geotextile (PLG) as schematically shown in Figure 1.

\section{B. Sample Testing and Analysis}

A wooden frame with dimensions of $300 \mathrm{~mm} \times 200$ $\mathrm{mm}$ was used in order to weave the geotextile to its desired dimensions. Two (2) samples of pineapple leaves geo-textile were used.

The J.A. King Pneumatic Sample Cutter was used to cut two (2) circular test specimens that were used for the test for Mass per unit area and Nominal Thickness. It is available in 5" or 6" diameter bore cylinders, provides 1960 or $2825 \mathrm{lbs}$ of force (respectively) at 100PSI.

The Zwick/Roell Tensile Strength Tester Z050 (CRE) with $50 \mathrm{KN}$ full scale load was used with the Wide-Width Strip Method in order to get the average tensile strength of two (2) test specimens each for both pineapple and abaca geotextile samples. It is able to test tensile strength up to 11,000 pounds and can be used to test materials ranging from thin tissue paper to high-performance fabrics and composite laminates.

The J.A. King Pneumatic Sample Cutter used the SDL thickness gauge M034A with $25 \mathrm{~cm}^{2}$ pressure foot area subjected to $2 \mathrm{kPa}$ to find the nominal thickness of the two (2) circular test specimens.

To be able to determine the different characteristics of the specimens produced and further improve the end product of this study, the following test and analysis were defined and conducted.

\section{Polyfelt specifications for geo-textile for non- woven geo-textiles}

As used in the study, this serves as the basis of comparison of average of tensile strength resulting from pineapple leaf and abaca geo-textiles. This determines whether the pineapple leaf is a viable raw material in producing natural fiber geo-textile.

In addition, Polyfelt Specifications for non-woven geo-textiles are used for mechanically bonded nonwoven geo-textiles and manually manufactured textiles. This is use to ensure excellent filtration properties with high water permeability and optimum soil retention capabilities, even when subject to high mechanic and hydraulic stress. This includes test requirements for tensile strength, nominal thickness, mass per unit area, trapezoidal tear, grab strength and California bearing ratio (CBR)(Bolt, 2010).

The tests conducted for this study were limited to the determination of tensile strength and nominal strength based on Polyfelt Specification due to unavailability of equipment during the conduct of this study. Polyfelt
Specification on tensile strength is categorized as Filtration-58, Filtration-68 and Filtration-78.

Filtration-58 was used as a category under the specification for non-woven geo-textile characterized by a two layer mechanically bonded continuous filament non-woven geo-textile with tensile strength of $24 \mathrm{KN} / \mathrm{m}$ and with elongation at maximum load of 90/40 percent.

Filtration-68 was used as a category for a two layer mechanically bonded continuous filament non-woven geo-textile with tensile strength of $30 \mathrm{KN} / \mathrm{m}$ and with elongation at maximum load of $90 / 40$ percent.

Moreover, Filtration-78 was also for a two layer mechanically bonded continuous filament non-woven geo-textile with tensile strength of $35 \mathrm{KN} / \mathrm{m}$ and with elongation at maximum load of $90 / 40$ percent.

For the Nominal Thickness, thickness values are required in calculation of some geo-textile and geomembrane parameters such as permeability coefficient, tensile stress (index), and the like.

The thickness of some geo-synthetics may vary considerably with the applied normal load. Specific pressures and surfaces on which they are applied are indicated on this method to ensure all results are comparable. (ASTM D5199-12, 2015).

\section{RESULTS AND DISCUSSION}

\section{A. Comparison of Pineapple Leaves geotextile and} Abaca geotextile Properties based from the test results

Table 1 presents the Nominal Thickness of the specimens. Based from the data drawn, the average nominal thickness of pineapple leaves geotextile and abaca geotextile are $9.63 \mathrm{~mm}$ and $10.3 \mathrm{~mm}$ respectively. Therefore, we can say that pineapple leave geotextile is thinner than the commercially abaca geotextile with a difference of $0.67 \mathrm{~mm}$.

Table 1. Nominal Thickness of Specimens

\begin{tabular}{cc}
\hline Test Sample & Average (mm) \\
\hline Pineapple Leaves Geotextile & 9.63 \\
Abaca Geotextile & 10.3 \\
\hline
\end{tabular}

Therefore, pineapple leaves geotextile has lower nominal thickness compared to the commercially available geotextile.

Table 2. Tensile Strength of Test Specimens 
The Third International Conference on Civil Engineering Research (ICCER) August $1^{\text {st }}-2^{\text {nd }} 2017$, Surabaya - Indonesia

\begin{tabular}{cc}
\hline Pineapple Leaves Geotextile & 31.886 \\
Abaca Geotextile & 29.0 \\
\hline
\end{tabular}

Table 2 presents the tensile strength of pineapple leaves geotextile and abaca geotextile using $300 \mathrm{~mm} \mathrm{x}$ $200 \mathrm{~mm}$ samples.

Based on the above table, the average tensile strength of pineapple leaves geotextile and abaca geotextile, which are $31.886 \mathrm{KN} / \mathrm{m}$ and $29.0 \mathrm{KN} / \mathrm{m}$ respectively. It clearly shows that pineapple leave geotextile has higher tensile strength compared to that of the commercially abaca geotextile with a difference of $2.886 \mathrm{KN} / \mathrm{m}$.

\section{B. Tensile Strength of Pineapple Leaves Geotextile and Abaca geotextile.}

The tensile strength of both Pineapple leaves and Abaca Geotextiles were tested. The tests results will be very useful in the study because high tensile strength is one of the most important characteristics of a good and reliable geotextile.

Figure 2 presents the comparison between the average tensile strength of pineapple leaves geotextile and abaca geotextile. The figure shows that pineapple leaves geotextile have higher tensile strength than abaca geotextile which is about $31.886 \mathrm{KN} / \mathrm{m}$ and 29.0 $\mathrm{KN} / \mathrm{m}$ respectively with difference of $2.886 \mathrm{KN} / \mathrm{m}$.

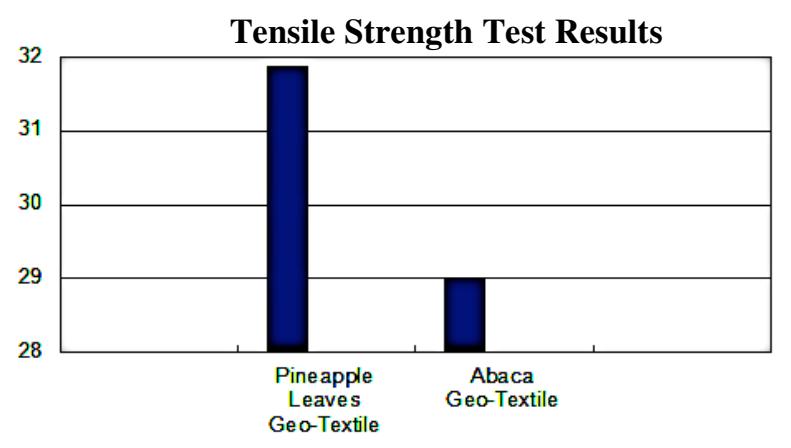

Figure 2. Tensile Strength Test Results

C. Comparison of Average Tensile Strength of Pineapple Leaves geotextile to Polyfelt Specifications for Non - Woven Geotextiles.

Table 3 presents the average tensile strength of pineapple leaves geotextile as compared to Polyfelt Specifications for non - woven geotextile. The average value for pineapple leave geotextile, F58, F68, and F78 specifications are $31.886 \mathrm{KN} / \mathrm{m}, 24.0 \mathrm{KN} / \mathrm{m}$, $30.0 \mathrm{KN} / \mathrm{m}$, and $35.0 \mathrm{KN} / \mathrm{m}$ respectively.

Table 3. Tensile Strength of Test Specimen and Polyfelt Specifications

\begin{tabular}{ccccc}
\hline Test Sample & $\begin{array}{c}\text { Average } \\
(\mathrm{KN} / \mathrm{m})\end{array}$ & $\begin{array}{c}\text { Filtration } \\
58 \\
(\mathrm{KN} / \mathrm{m})\end{array}$ & $\begin{array}{c}\text { Filtration } \\
68 \\
(\mathrm{KN} / \mathrm{m})\end{array}$ & $\begin{array}{c}\text { Filtration } \\
78 \\
(\mathrm{KN} / \mathrm{m})\end{array}$ \\
\hline $\begin{array}{c}\text { Pineapple } \\
\text { leave } \\
\text { geotextile }\end{array}$ & 31.886 & 24.0 & 30.0 & 35.0 \\
$\begin{array}{c}\text { Abaca } \\
\text { geotextile }\end{array}$ & 29 & 24.0 & 30.0 & 35.0 \\
\hline
\end{tabular}

The above table clearly shows that Pineapple leaves geotextile conforms to Filtration 58 standard of Polyfelt Specifications for non-woven geotextile.

\section{Tensile Strength of Test Samples and Polyfelt Specifications}

To ensure that pineapple leaves are a good and reliable geotextile the sample, it was then compared with the specifications for non - woven geotextile.

Figure 3 presents the average tensile strength of pineapple leaves geotextile as compared to Polyfelt Specification for non - woven geotextile. Pineapple leaves geotextile, as presented in the graph, Pineapple leaves geotextile got the value closest to that of F68, considering F68 as the second highest value of Polyfelt Specification for non - woven geotextile with $30.0 \mathrm{KN} / \mathrm{m}$ tensile strength. The graph simply shows that pineapple leaves geotextile is classified as F-68 based on the Polyfelt Specification for non-woven geotextile.

\section{Comparison of Pineapple Leaves Geotextile Tensile Strength to Polyfelt Specification}

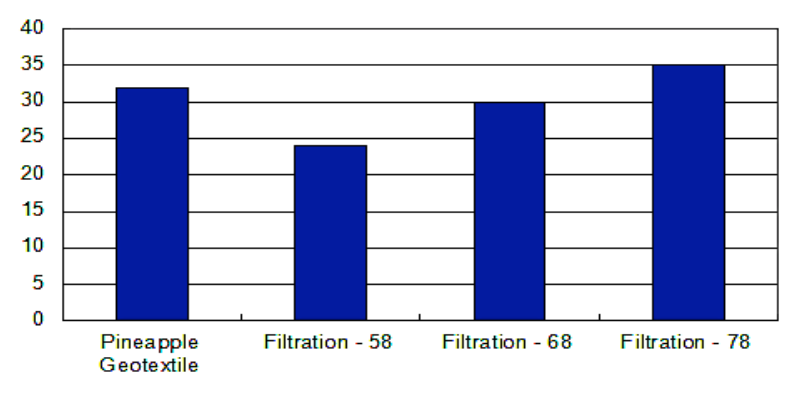

Figure 3. Comparison of the Average Tensile Strength of Pineapple Leaves Geotextile

\section{CONCLUSION}

The study arrived at a conclusion that the Pineapple leaves, as alternative natural fiber geotextile is viable. Based on test results, Pineapple leaves geotextile has proven to have property comparable to the commercially available geotextile based on Polyfelt Specification for non-woven geotextile. The average nominal thickness of pineapple leaves geo-textile is 
The Third International Conference on Civil Engineering Research (ICCER) August $1^{\text {st }}-2^{\text {nd }}$ 2017, Surabaya - Indonesia

$9.63 \mathrm{~mm}$ and the average tensile strength of it was $31.886 \mathrm{KN} / \mathrm{m}$. Pineapple leaves geo-textile is thinner than that of the abaca geo-textile. On the other hand, Although Pineapple leaves geo-textile is thinner than the Abaca geotextile, tests show that it can sustain a tensile strength higher that of abaca geotextile. Lastly, the pineapple leaves geotextile has an average tensile strength value of $31.886 \mathrm{KN} / \mathrm{m}$, which is under the category of filtration-68, therefore higher than that of commercially available geotextile.

\section{ACKNOWLEDGEMENT}

The researchers wish to express our gratitude to the people who have made this research possible.

We would like to thank Prof. Rosemarie Robles for her insightful comments.

Lastly, we would like to thank our family for the spiritual support and guidance.

\section{REFERENCES}

[1] J.K. Stephen Corbet, Geotextiles in Filtration and Drainage, Cambridge United Kingdom: M. Heilbaum Bundesanstalt fur Wasserbau Publishers, 1993

[2] C. Lin, Soils and Foundation, Engle Wood Cliff, New Jersey: Prentice-hall Inc., 1981

[3] G. V. Santvoort, Geotextiles and Geomembranes in Civil Engineering Revised Edition. Nethelans: A.A. Balkema Publishers, Old Post Road, Brookfield, VT05036, USA, 1994

[4] G. M. Alcantara, "Viability of Pineapple leaves as raw materials in Production of Fiberboard", Batangas State University, 2013.
[5] L. M. Laroza, "Viability of Banana Sheath as an Alternative Natural Fiber Geotextile", Batangas State University, 2014

[6] Khan, A. J., "Quality Control of Jute Geotextiles \& Development of Testing Facilities. Bangladesh", Bangladesh Jute Research Institute, 2010

[7] Department of Agriculture - HVCDP, (2013). Department of Agriculture High Value Crops Development Program (RA 7900). Available: http://hvcdp.da.gov.ph/pineapple.htm

[8] Kentucky Transportation Cabinet. (n.d.).5Slope Protection. Available: http://transportation.ky.gov/EnvironmentAnalysis/Env ironment\%20Resources/3-Slope\%20Protection.pdf

[9] Mahuya Ghosh, (2009). Suitability of Natural Fibers in Geotextile Applications [Online]. Available: http://gndec.ac.in/ igs/ldh/conf/

[10] 2009/article 55555555s/T07_40.pdf

[11] Ministry for the Environment. (2009, August 24). Soil intactness of erosion-prone land [Online] Available: www.mfe.goct.nz/environmental5555reporting/land/erosion-risk/ 